\title{
Criminal Liability for Environmental Damage - National Courts Versus the International Tribunal for the Law of the Sea
}

\author{
Shams Al Din Al Hajjaji*
}

DOI: $10.21827 / 59 \mathrm{db} 695 \mathrm{fa} 197 \mathrm{a}$

\begin{abstract}
This article argues to abolish Criminal Liability for Environmental Damage in order to consider legislative amendments, which comply with the rulings of ITLOS. There is a discrepancy between plaintiffs who are able to present their cases to ITLOS and those who are unable to do so. In most fishery cases, plaintiffs are unable to resort to ITLOS and national courts deal with these cases based on their own understanding, not that of ITLOS. The article differentiates between Criminal Liability for Environmental Damage (RLED) and Civil Liability for Environmental Damage (CLED). It also provides examples and explanations for the difference between them. This article is divided into four main sections. The first tackles the theoretical difference between CLED and RLED. The second section presents six cases in which the ITLOS has dealt with the question of national RLED. The cases show how ITLOS transforms RLED to CLED. The third section highlights discrepancies in the practice of both international and national courts with regard to two issues: confiscation and bond determination in fishery cases. The fourth and last part recommends a solution to overcome discrepancies between national and international courts.
\end{abstract}

\section{Introduction}

The United Nations Convention on the Law of the Seas (UNCLOS) adopts Civil Liability for Environmental Damage (CLED) to settle international environmental disputes. ${ }^{1}$ When both, national and international courts adopt CLED the issue of complementarity does not arise. ${ }^{2}$ Discrepancies arise when national courts adopt Criminal Liability for Environmental Damage (RLED) and international courts adopt

* Shams Al Din Al Hajjaji is a judge at North Cairo Primary Court. The author wishes to extend his deep gratitude and appreciation to Lila Sheira, Claire Weyland and the Editors of the Groningen Journal of International Law for their constructive comments and helpful edits, and my wife for her continuous help and support.

1 Many States, such as the US and Canada, adopt Civil Liability for Environmental Damage (CLED) as a method of tackling environmental violations. For the United States, United States Environmental Protection Agency, Clean Air Act, Stationary Source Civil Penalty Policy (25 October 1991) at <epa.gov/sites/production/files/documents/penpol.pdf> (accessed 11 July 2017). See also, Willis, J, "On Environmental Services Group" (2005) at <aon.com/risk-services/environmentalarticles/article_ins-civil-finespen.jsp> (accessed 11 July 2017). For Canada, Environment and Climate Change Canada, "Administrative Monetary Penalty System - Consultation Document" (27 July 2013) at <ec.gc.ca/alef-ewe/default.asp?lang=En\&n=465314E0-1\&offset=2\&toc=show> (accessed 11 July 2017).

2 Other countries, such as France, Russia, and Brazil, still adopt Criminal Liability for Environmental Damage (RLED). Whereas many countries strive to lower their environmental standards to facilitate trade and maximise economic benefits. As for France and Russia, the research details the environmental cases include criminal liability. As for Brazil, see Gonçalves, ED, Garcia, LP, et al, "Environmental Law and Practice in Brazil: Overview" (1 October 2012) at <us.practicallaw.com/2508-8459> (accessed 11 July 2017). 
CLED. UNCLOS Member States resort to the International Tribunal for the Law of the Seas (ITLOS) to overcome consequences arising from the adoption of RLED. As a result, States, especially UNCLOS Member States, should abolish RLED, as this research argues, in order to fully comply with the decisions of ITLOS, in relation to CLED.

When the nature of the dispute escalates, from a matter of RLED on the national level, to CLED, on the international level, this will not only raise challenges regarding its outcome but will also violate both the national and international litigants' right to legal prediction of risk in the dispute. ${ }^{3}$ For example, fishermen can more often than not predict the outcome of their illegal behavior. If the law imposes fines as a punishment for a certain violation, adopting detention as a new legal policy violates the defendant's right to predict the consequences of his behavior. Also, it is considered a great waste of resources if prosecutors or judges are unable to foresee the decisions of the highest courts, whether national or international. ${ }^{4}$

On the international level, litigants have the right to predict the litigation risk, which includes the right to predict the outcome of the dispute. The change in the nature of the dispute from RLED to CLED affects the right of parties to predict tribunal proceedings. ${ }^{5}$ ITLOS adopts a CLED approach to settling disputes. ${ }^{6}$ This research aims, above all, to provide direction and vision to states and lawyers who deal with fishery cases on the international level. This research is especially relevant for countries that adopt RLED in their national legislation. ${ }^{7}$ Highlighting two major issues, bond determination and confiscation, can help lawyers avoid long and costly litigation processes on both national and international levels. ${ }^{8}$

The article is dedicated to study the difference between RLED and CLED as well as the difference in rulings between national and international courts. Two legal questions showcase the discrepancies: bond determination, and confiscation in fishery cases. ${ }^{9}$ Regarding bond determination, while CLED and RLED ensure the right of a state to impose their directions, they differ in the way bonds are determined. As for confiscation, both CLED and RLED have different methods in determining the subject of confiscation. ${ }^{10}$

This article verifies its claim through two legal approaches: the positive law approach, and the comparative law approach. Firstly, the positive law approach is based on the rule of law applied in international conventions, proceedings, principles as well as customs. Article 38 of the Statute of the International Court of Justice denotes that the ITLOS is allowed to use treaties, customs or general principles of international law in its

3 Kaye, T, "Risk and Predictability in English Common Law" in Woodman, G and Klippel, D, eds, Risk and The Law (Routledge-Cavendish 2009), 108.

Ibid.

5 Manning, P, "Reflections on Risk Analysis, Screening and Contested Rationalities" 48(3) Canadian Journal of Criminology and Criminal Justice (2006) 453, 460.

6 Escher, A-K "Release of Vessels and Crew Before the International Tribunal for the Law of the Sea" 3(2) The Law and Practice of International Courts and Tribunals (2004) 205, 205. See also, Ratliff, D, "Dispute Resolution and Environmental Security" 20 Hague Yearbook of International Law (2007) 65.

7 Oxman, BH, "Complementary Agreements and Compulsory Jurisdiction" 95(2) The American Journal of International Law (2001) 277, 278- 283.

$8 \mathrm{Ibid}, 284$.

9 McDorman, TL, "An Overview of International Fisheries Disputes and the International Tribunal for the Law of the Sea" 40 Canadian Yearbook of International Law (2003) 119, 120-121.

10 Ibid, 124. 
judicial processes. ${ }^{11}$ ITLOS uses UNCLOS and its case law as primary sources for its judgments.

The second methodology is that of a comparative law approach. The scope of this research lies in striking a comparison between CLED and RLED within national and international courts. The relationship between international law and national law is depicted in the principle of complementarity. This principle gives priority and preference to national courts over international courts in disputes. ${ }^{12}$ Moreover, RLED is applied exclusively on the national level, while CLED is used on both levels. ${ }^{13}$ This study urges countries that adopt RLED to restructure and reform their national laws in the hope of complying with international standards. ${ }^{14}$ The inclusion of countries' practices and an understanding of RLED can to a great degree help avoid discrepancies in environmental disputes between national and international courts.

This article is divided into four main sections. The first section examines the theoretical difference between CLED and RLED. It compares States interests' with their corresponding goals, bond determination guidelines and confiscation methods followed by both CLED and RLED. The aim of the contrast is to present the different understanding of both concepts in theory. The second section presents six cases, where the ITLOS has dealt with the question of national RLED. The cases show how ITLOS converts RLED to CLED. The third section showcases inconsistencies in the practice of both international and national courts in relation to two issues: confiscation and bond determination in fishery cases. The article reveals differences between proceedings in international courts and judgments in national courts for the same set of facts. The fourth and last part of the article recommends a key to overcome discrepancies that exist between national and international courts.

\section{Comparison between Civil and Criminal Liability for Environmental Damage}

The environment is a communal good, which makes it difficult to assign a monetary value to violations committed against it. ${ }^{15}$ Countries adopt either RLED or CLED when faced with such infringements. The key here will be the form that can more effectively restore the situation to its previous state. ${ }^{16}$ Yet, the difference between RLED and CLED is not unimportant. This depends on two major factors that characterize environmental liability as RLED or CLED ${ }^{17}$ The first entails the state's interest in the environmental dispute and highlight its objectives. The second is related to the application of RLED and CLED in fishery cases, which involves bond determination and confiscation.

Firstly, the State and the defendant have different takes in CLED and RLED countries regarding environmental disputes. ${ }^{18}$ In RLED systems, the governmental status

11 Article 38(1), United Nations, Statute of the International Court of Justice (18 April 1946).

12 Brown, B "Primacy or Complementarity: Reconciling the Jurisdiction of National Courts and International Criminal Tribunals" 23 Yale Journal of International Law (1998) 383, 389. See also Oxman, BH, "Complementary Agreements and Compulsory Jurisdiction" 95(2) The American Journal of International Law (2001) 277, 278- 283.

13 Ibid.

14 Ibid.

15 Siebert, H, Economics of the Environment: Theory and Policy, ( $7^{\text {th }}$ ed, Springer 2008), 19.

$16 \mathrm{Ibid}, 850$.

17 Brickey, KF, "Environmental Crime at the Crossroads: The Intersection of Environmental and Criminal Law Theory" 71 Tulane Law Review (1996) 487, 507-511.

18 Carlsson, L, "Mark Wilde, Civil Liability for Environmental Damage - A Comparative Analysis of Law and Policy in Europe and in the United States, The Hague, Kluwer Law International, 2002" 15(1) Revue Québécoise de Droit International (2002) 247-248. 
supersedes that of the defendant. This is based on the government's prerogative to guard its own environment. ${ }^{19}$ Even though countries have separate environmental codes, they use criminal law tools to stand against environmental damage, and criminalize certain acts. ${ }^{20}$ Governments punish both individual and corporate actions in an attempt to enforce and achieve the purposes and aims of criminal justice. ${ }^{21}$ In CLED systems, the State holds an equal position to the defendant. ${ }^{22}$ In fishery-related cases with CLED, the government tolerates a certain level of harm, whereas defendants reserve a certain right to harm the environment. The court tries to strike a balance between social profit and social harm. ${ }^{23}$

Secondly, CLED and RLED have different rules of application. In CLED countries, only curative and remedial action is obtainable for excessive harm to the environment. ${ }^{24}$ International Environmental Law deals with the protection of the environment, and aims to increase multi-lateral cooperation among the international community. ${ }^{25}$ It deals with environmental defilements as CLED. For RLED, it is not only restorative and remedial actions that are available; but also disciplinary action is taken. ${ }^{26}$ Governments play a major role in minimizing environmental harm through RLED, while preventing the defendant from gaining any potential economic profit. ${ }^{27}$

Thirdly, RLED and CLED are not different in bond determination. However, CLED and RLED differ when it comes to the objective of the bond. In CLED systems, the only aim of the bond is ensuring that the plaintiff will comply with any financial obligations that result from the judgment. For RLED, the aim of the bond is to safeguard not only the presence of the defendant in court, but also the protection of others within the community. ${ }^{28}$ As a result, a bond determination in RLED countries, based on various factors, governs whether the court grants bail or not. These factors include:

1. The defendant's social upbringing, and past bail record ${ }^{29}$

2. The strength of the evidence, the nature and circumstances of the offence, as well as the weight of the evidence; ${ }^{30}$

3. The history and characteristics of the person, and the gravity of the danger to the community; ${ }^{31}$

4. Any other consideration that may be relevant to the present case. ${ }^{32}$

19 Stroup, RL, Economics: What Everyone Should Know About Economics and the Environment (Cato Institute 2003), 39.

20 Ibid, 40.

21 Posner, RA, "Henry Hart's "Aims of the Criminal Law': A Reconsideration" in Lynch, T (ed), In the Name of Justice: Leading Experts Reexamine the Classic Article "The Aims of the Criminal Law" (Cato Institute 2009), 96-97.

22 Ibid.

23 Krugman, P, et al, Economics in Modules (3 $3^{\text {rd }}$ ed, Worth Publishers 2015), 115.

24 Ibid.

25 Bodansky, D, The Art and Craft of International Environmental Law (Harvard University Press 2010), 21.

26 Ibid, 22.

Ibid, 23.

$\S 18$ U.S.C. $3142(\mathrm{~g})$

29 Corre, N and Wolchover, D, Bail in Criminal Proceedings (2 $2^{\text {nd }}$ ed, Blackstone Press 1999), 26.

30 Cal. Pen. Cod $\S 1275$.

9 Cal. 3d 345, 405 (1973).

$32 \S 18$ U.S.C. $3142(\mathrm{~g})$. 
Finally, the issue of confiscation has been scrutinized for both CLED and RLED. In CLED systems, only civil confiscation is permissible. For RLED, there are two types of confiscation: civil and criminal. The US Supreme Court does not count civil forfeiture as a punishment. ${ }^{33}$ It maintains that civil and criminal confiscation/forfeiture can take place simultaneously in certain cases. ${ }^{34}$ It entails that in rem civil forfeiture neither calls for disciplinary, nor punishable acts. ${ }^{35}$ The court asserts that Congress has authorized the government to 'seek parallel in rem civil actions and criminal prosecutions based on the same underlying events. ${ }^{36}$ The discrepancy between criminal and civil confiscation lies in their direct connection to the gain obtained from the unlawful behavior. Criminal confiscation is concerned with crime materials and substance, whereas civil seizure applies to any product that can be traced back to these materials or substance, including illegal fish catch. In an attempt to initiate the procedure of confiscation, the court has to establish that the defendant has received financial gain from his criminal act. In the UK, courts take into consideration the least amount of economic gain that defendants have gained from their activity. ${ }^{37}$ The determination of the amount of profit gained by the defendant from the crime is calculated based on 'the provisions governing the submission of a statement, or statements, about the defendant's economic dealing and realizable property. $^{38}$

\section{ITLOS Cases Dealing with National RLED}

\section{A. The 'Tomimaru' Case: Japan versus the Russian Federation, 2007}

A Japanese company owns and operates the fishing ship. ${ }^{39}$ The vessel was licensed to fish for walleye Pollock and herring between 1 October and 31 December $2006 .{ }^{40}$ The vessel was only given permission to fish in the Western Bering Sea, which is located in the exclusive economic zone (EEZ) of the Russian Federation (RF). The vessel was allowed a maximum load of 1,163 tons of walleye Pollock, as well as 18 tons of herring. ${ }^{41}$

On the last day of the license's validity, Russian inspectors were conducting random inspection rounds and boarded the fishing vessel while it was in the Russian EEZ. Reviewing the license and the maximum allowed catch, inspectors found on board the vessel an extra load of 5.5 tons of walleye Pollock, exceeding the granted load, and the limit of the fishing license. ${ }^{42}$ They also found another ' 20 tonnes of gutted walleye Pollock, that was not listed in the logbook' ${ }^{43}$ They also came to find various 'kinds of fish products which are forbidden to catch [sic]'. This catch ranged from large quantities of different types of halibut and ray to cod. The amount of illegal catch was 'estimated to be $62,186.9 \mathrm{~kg}$ and the damage to the living resources in the RF amounted to 8,800,000 rubles $(\$ 345,000){ }^{4}{ }^{44}$

33 Pratt, GC, and Petersen, WB, "Civil Forfeiture in the Second Circuit" 65(3) St John's Law Review (1991) $653,668$.

34 Sweeny, JC, "The Silver Oar and Other Maces of Admiralty: Admiralty Jurisdiction in America and the British Empire" 38(2) Journal of Maritime Law and Commerce (2007) 159.

35 518 U.S. 267 (1996).

36 Kaye, supra nt 35.

37 McCutcheon, JP, and Walsh, D, The Confiscation of Criminal Assets: Law and Procedure (Round Hall Ltd 1999), 64.

38 Ibid, 65.

39 The Tomimaru Case, Japan v. Russian Federation, (2007) 22.

40 Ibid, 23.

41 Ibid, 23.

42 Ibid, 24.

43 Ibid, 25.

44 Ibid, 25. 
On 8 November 2006, a criminal case was constituted against the vessel and its master. The master was given restraining orders not to leave the country till the end of the investigation. ${ }^{45} \mathrm{He}$ was charged with 'exploitation without permission of the natural resources in the EEZ of the Russian Federation, causing enormous environmental harm to the living marine life, equivalent to $8,500,000$ rubles. ${ }^{46}$ The fishing vessel Tomimaru was confiscated on basis of Article 82 of the Code of Criminal Procedure as a piece of evidence. Part of the illegal catch was confiscated, whereas the rest was sold and the returns were paid to the owner. ${ }^{47}$

On 1 December 2006, the owner of the vessel had failed to pay the bond set by the Russian government to release the ship. In communication with the Consulate General of Japan, the prosecutor's office asserted that the bond was set, not only to release the ship, but also to guarantee payment of the judicial cost. ${ }^{48}$ On 8 December 2006, the owner of the vessel had pleaded in a petition to the prosecutor's office to set a separate bond to release the ship, rather than paying the full sum of the damage incurred. This request was denied until the full sum of the damage was paid. ${ }^{49}$

On 14 December, the vessel owner petitioned once more the Northeast Border Coast Guard Directorate. ${ }^{50}$ The case was sent to the City Tribunal of PetropavlovskKamchatskii, and again the petition was denied. ${ }^{51}$ On 28 December 2006, the Petropavlovsk-Kamchatskii City Tribunal found the owner accountable for the harm incurred by the ship. ITLOS condemned the owner with a total fine of 'double the cost of biological (living) aquatic resources ... and [ruled] to seize the $53^{\text {rd }}$ Tomimaru vessel. ${ }^{, 52}$ On 24 January 2007, another appeal was filed to annul the District Tribunal's decision ${ }^{53}$ which was still pending at the time of filing the case in front of ITLOS. ${ }^{54}$

On 26 March 2007, an action was taken in the Supreme Tribunal of the RF, under the supervisory review process against the District Tribunal pronouncement. ${ }^{55}$ On 26 July 2007, the Supreme Tribunal of the RF dismissed the case for failing to identify any legal grounds for review of the complaint. ${ }^{56}$ On 9 April, 2008 the Federal Agency on Management of Federal Property ordered the seizure of the vessel for the benefit of the RF. ${ }^{57}$

\section{B. The 'Hoshinmaru' Case: Japan versus Russian Federation, 2007}

Hoshinmaru is a Japanese fishing vessel. ${ }^{58}$ On 14 May 2007, the RF has granted the owner a fishing license for salmon, tuna and trout within its EEZ within the period from 15 May to 31 July 2007. The amount granted to the vessel was 101.8 tonnes of sockeye salmon, 161.8 tonnes of chum salmon, 7 tonnes of sakhalin trout, 1.7 tonnes of silver salmon, and 2.7 tonnes of spring salmon. ${ }^{59}$

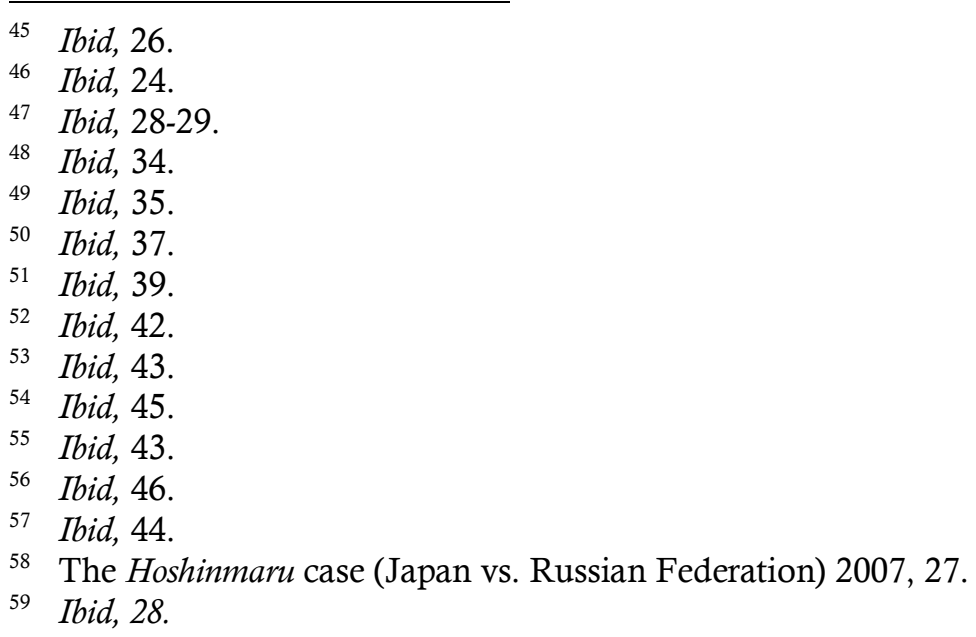


On 1 June 2007, a Russian patrol boat stopped the Hoshinmaru on its course within the RF's EEZ off the eastern cost of the Kamchatka peninsula. A squad of state sea inspectors of the northeast border coast guard directorate, part of the Federal Security Service of the RF (hereinafter State Sea Inspection), found that 'under the upper layer of chum salmon, sockeye salmon were found [sic].' The inspectors considered such an act to be a falsification of data recorded in the fishing log and the daily vessel report. On 2 June 2007, a protocol of detention stated the reason for the vessel's seizure was 'holding untrue and falsified operational accounts in the daily vessel report, creating a discrepancy between the amount permitted of fish, and the actual catch on board. ${ }^{60}$

On 4 June 2007, the Military Prosecutor's Office initiated administrative proceedings against the owner of the Hoshinmaru for violating the rules of catching (fishing) of aquatic biological (living) resources. ${ }^{61}$ On 26 June 2007, a criminal case was filed against the master of the Hoshinmaru for illegitimate fishing. On 11 July 2007, communication transpired between the inter-district prosecutor's office and the Consulate General of Japan to identify the damage incurred to be equivalent to 7,927,500 rubles for harm against living aquatic resources by the illegal catch. ${ }^{6}$

On 13 July 2007, the Ministry of Foreign Affairs of the RF communicated with the Embassy of Japan to set the bond at 25 million rubles, including the aforementioned amount of damages. The RF affirmed that once the bond was paid the seventeenmember crew, and the ship would be released. During the hearings of the trial the RF agreed to reduce the bond from 25 to 22 million rubles. ${ }^{63}$

\section{The 'Volga' Case: Russian Federation versus Australia, 2002}

The Volga is an RF fishing vessel. ${ }^{64}$ Both the ship's flag and owner were Russian. ${ }^{65}$ The vessel was granted a license for commercial fishing from the RF. ${ }^{66}$ On 7 February 2002, Australian military personnel came on board of the shipping vessel for their regular rounds of inspection. The vessel was located at a point 'beyond the limits of the EEZ of the Australian Territory of Heard Island, and the McDonald Islands. ${ }^{67}$

The officers of the Royal Australian Navy, and the Australian Fisheries Management Authority issued a notice of seizure. The report stated that the vessel was illegally fishing in the EEZ, in violation of the Australian Fisheries Management Act of 1991. ${ }^{68}$ On 19 February 2002, the vessel was escorted to the Western Australian port of Fremantle. The ship's master and crew were 'detained following a notice of confinement issued under the Fisheries Management Act 1991. ${ }^{69}$ The purpose of the detention was to evaluate the incident and determine charges against them in agreement with the law. ${ }^{70}$

On 27 February 2002, the Australian authority issued a report that set a bond of AU $\$ 147,460$ against the ship. ${ }^{71}$ On 6 March 2002, the master and the crew were charged with engaging in illegal commercial fishing in the absence of a license or permission from the competent authorities. The three crew members were released on bail set at

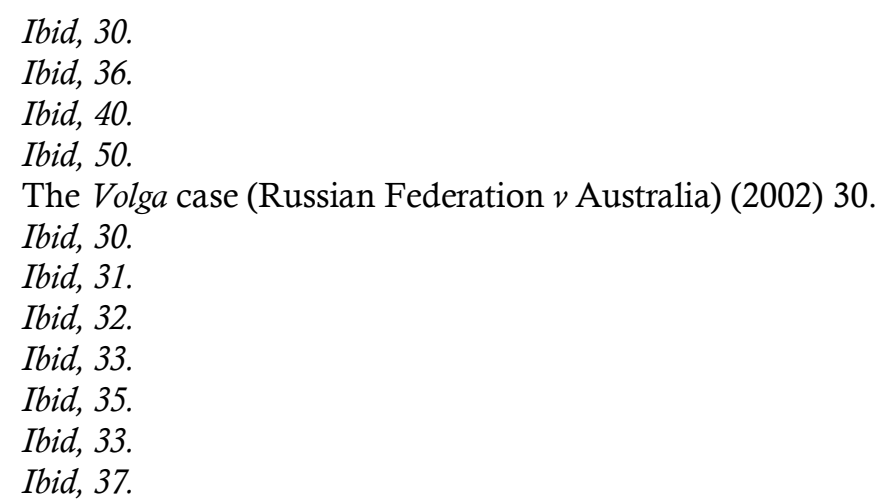


AU \$75,000 each. The bail was determined on three conditions: (1) the crew members had to reside at a place that is known and can be located by the supervising fisheries officer with the Australian Fisheries Management Authority; (2) the passports of the three crew members were given to the authorities, and (3) the crew members were confined to Perth, Western Australia. ${ }^{72}$ On 16 March 2002, the master of the ship died in a hospital before charges were pressed against him. ${ }^{73}$ On 30 May 2002, the crew members successfully obtained 'a variation of the bail conditions. ${ }^{74}$ They were able to return to their homeland, under certain conditions, awaiting criminal proceedings against them. The Australian authority sold the entire amount of fish found on board the vessel, based on the ruling of the Fisheries Management Act 1991. The amount of the catch was estimated at 131.422 tonnes of Patagonian toothfish and 21.494 tonnes of bait. The price for the sold catch was AU $\$ 1,932,579.28 .^{75}$

On 21 May 2002, proceedings were issued to stop the 'forfeiture of the vessel, fish, nets and equipment. ${ }^{76}$ On 26 July 2002, the Australian Fisheries Management Authority required a bond of AU $\$ 3,332,500$ for the release of the vessel. The bond amount was set based on three factors: (1) the value of the vessel, fuel, lubricants and fishing equipment, (2) the potential fines, and (3) the cost of the 'conservation measures until the conclusion of legal proceedings. ${ }^{77}$ On 23 August 2002, further charges were brought against the master of the ship. On 16 December 2002, a new bail of AU\$20,000 was set for the master of the ship, who was by then dead, and the bail paid by the owner of the ship. ${ }^{78}$ Hence, the bail for the master was AU\$95,000 and AU\$75,000 for each of the three crew members. ${ }^{79}$

\section{The 'Grand Prince' Case: Belize versus France, 2001}

The Grand Prince is a Belizean fishing vessel with an owner of the same nationality. ${ }^{80}$ The vessel was on its way to change its flag to the Brazilian flag. ${ }^{81}$ The master of the vessel was Spanish, while its 37 crew members were citizens of Spain and Chile. ${ }^{82}$ On 26 December 2000 the vessel departed from the French surveillance frigate Nivose. It was in the EEZ of the Kerguelen Islands in the French Southern and Antarctic Territories. A report was issued against the master of the vessel for committing two violations. The first was unauthorized fishing in the EEZ of the Kerguelen Islands under French jurisdiction. The second was the failure to announce its entry into the EEZ and the amount of fish on board the vessel. ${ }^{83}$

On 9 January 2001, the vessel was escorted to the town of Port-des-Galets, Réunion. ${ }^{84}$ Two days later, the Regional and Departmental Director of Maritime Affairs of Réunion seized the vessel. This decision was based on three factors: 1) the vessel was fishing in the French EEZ; 2) the entry into such zone was not declared to the competent

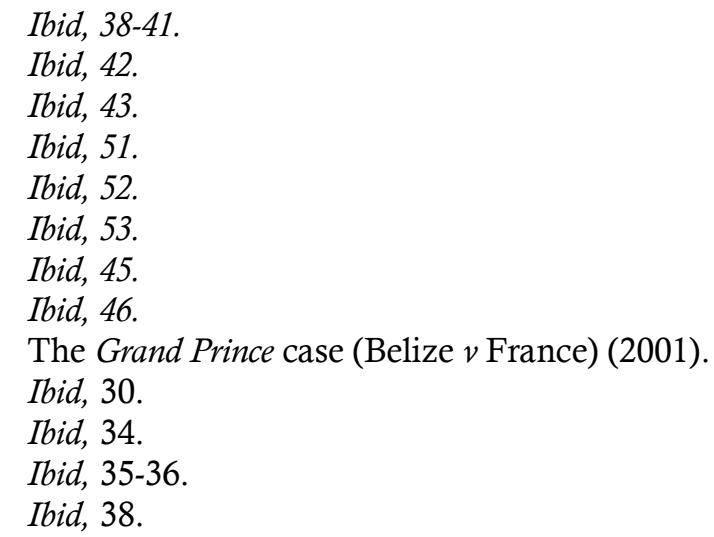


authority; 3) the French authorities saw evidence that commercial fishing had taken place. ${ }^{85}$ The Deputy Public Prosecutor summoned and informed the master of the charges, which he admitted. The master of the vessel indicated that he started the illegal fishing in December 2000. ${ }^{86}$

On 12 January 2001, the court of first instance ruled against the vessel based on the charges of the prosecution. The court found that the vessel entered the EEZ without authorization. The vessel additionally had not declared the amount of fish on board; this raised the suspicion that 18 tonnes of toothfish had been illegally caught within the French EEZ. ${ }^{87}$ The court then fixed a bond of 11,400,000 French Francs (FF). ${ }^{88}$ The court based the bond on the value of the ship, the potential fines that the law imposes on the vessel's master, and the average compensation in such cases. ${ }^{89}$ It also took other factors into consideration, such as a bond to ensure that the master would be represented at trial, a bond to ensure payment of the damages, and a bond to grant the payment of the confiscation of the vessel..$^{90}$ Furthermore, the court ordered, in accordance with both the French Penal Code and the Code of Penal Procedure, the confiscation of the vessel without waiting for an appeal to be lodged. It also sentenced the master of the vessel to a fine of FF200,000. The court took into consideration that he was cooperative with the competent authorities. ${ }^{91}$

\section{E. The 'Camouco' Case: Panama versus France, 2000}

The Camouco is a Panamanian fishing vessel owned by a company registered in the same country. ${ }^{92}$ The vessel had a fishing license for 'longline fishing of Patagonian toothfish in international waters in the South Atlantic Ocean. ${ }^{93}$ On 16 September 1999, the vessel engaged in longline fishing after leaving Walvis Bay in Namibia. ${ }^{94}$ A French surveillance frigate boarded the vessel while it was in the EEZ of the Crozet Islands. ${ }^{95}$ The ship had been observed for two hours before moving away from the EEZ. When the French officials boarded the vessel, they found six tonnes of frozen toothfish, as well as 48 jettisoned bags, of which they were able to retrieve only one. ${ }^{96}$ The master of the Camouco was charged with breaking the law for unlawful fishing in the EEZ, failure to declare its presence in the EEZ while having fish on board, concealment of the vessel's markings, as well as attempts to avoid verification. ${ }^{97}$

On 29 September 1999, the French authorities escorted the vessel and issued an order to seize the vessel, the fish catch, the navigation and communication equipment and documents of the vessel and the crew..$^{98}$ On 5 October 1999, the Camouco arrived at Port-des-Galets, Réunion. ${ }^{99}$ On 7 October 1999, the Regional and Departmental Directorate of Maritime Affairs (RDDMA) reiterated the charges against the master. The

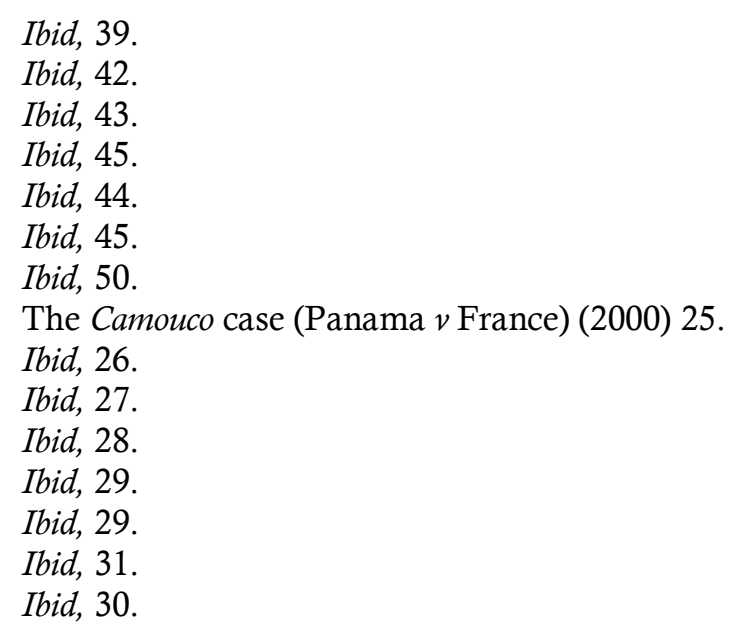


order seized the toothfish, estimated at $7,600 \mathrm{~kg}$, at a value of FF380,000, as well as the vessel, the value of which was estimated at FF20,000,000 ${ }^{100}$ Furthermore, the vessel's master was placed under court supervision.

On 8 October 1999, the court of first instance confirmed the procedures taken by the RDDMA. ${ }^{101}$ It also set a bond at FF20,000,000 ${ }^{102}$ The court based its decision on Article 3 of its national law concerning the regime of seizure and supplementing the list of agents authorized to establish offenses in matters of sea fishing, in addition to Article 142 of its Code of Criminal Procedure. On 22 October 1999, the vessel master filed a summons for urgent proceedings to secure the release of the vessel and to reduce the amount of the bond. ${ }^{103}$ The court of first instance rejected the request. At the time of the trial at ITLOS, an appeal against this order was still pending before the court of appeal.

\section{F. The 'Monte Confurco' Case: Seychelles versus France, 2000}

The vessel Monte Confurco is a shipping vessel flying the Seychelles flag, with the owner company located in the Seychelles. ${ }^{104}$ The license of the vessel is limited to fishing in international waters. In August 2000, the vessel left Port Louis (Mauritius) for longline fishing, its master a Spanish national. ${ }^{105}$

On 8 November 2000, the French surveillance frigate Floréal boarded the vessel while it was in the EEZ of the Seychelles. ${ }^{106}$ A procès-verbal was issued against the master of the vessel for: failure to announce his presence, the quantity of fish aboard the vessel, fishing without prior authorization, and the attempt to evade investigation by the 'agents responsible for policing fishing activities. ${ }^{107}$ A further order was issued to seize the vessel, the cargo, the catch, the navigation and communication equipment, computer equipment, and documents of the vessel and its crew. ${ }^{108}$ The vessel was then escorted to Port-des-Galets, Réunion. ${ }^{109}$

On 20 November 2000, the Regional and Departmental Director of Maritime Affairs of Réunion (RDDMA) based his charges against the master of the vessel for being in the French EEZ, and for having varied quantities of fish on board without declaring the amount or source of the catch. ${ }^{110}$ The estimated amount of fish found on the vessel was 158 tonnes with a value of FF9 million. This amount was sold and its revenue credited to the public treasury upon the conclusion of the case. The value of the ship, its equipment and documents was estimated at FF15 million by the French authorities. ${ }^{111}$ The RDDMA argued the court of first instance should set a bond at FF95,400,000 to release the vessel. ${ }^{112}$

On 21 November 2000, the master of the vessel was charged and placed under court supervision. He was additionally ordered not to leave Réunion. ${ }^{113}$ On 22 November 2000 , the court of first instance laid charges against the master of the vessel for

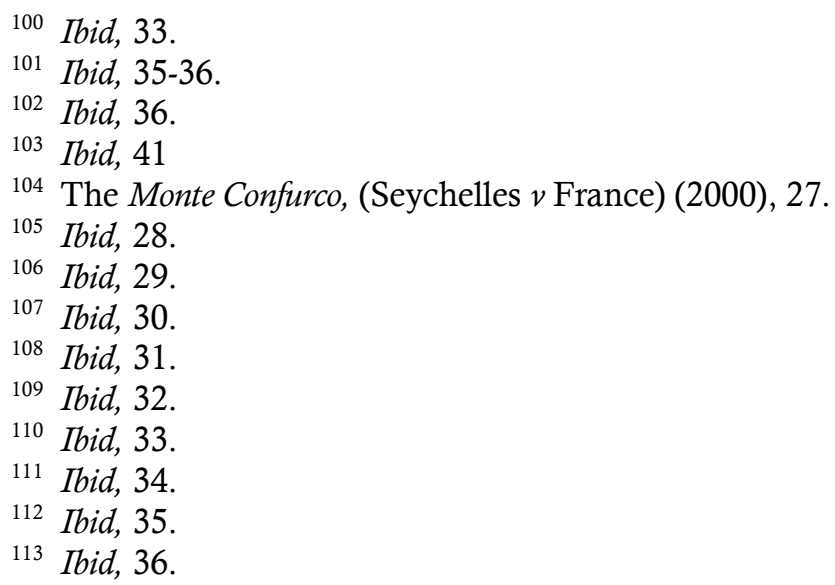


unauthorized entrance into the French EEZ, for not declaring the amount of fish on board, as well as for not giving notice before entering the EEZ. The court found that this lack of declaration of the catch on board was a sign of unlawful fishing. ${ }^{114}$

The court of first instance at Saint-Paul took into consideration certain factors to determine the amount of the bond. They included the value of the ship at FF15 million, the fines incurred by the master of the vessel, based on the value of 158 tonnes of illegal catch, at FF79 million, in addition to the average compensation in such cases at FF100,000. ${ }^{115}$ However, when the court of first instance set the final bond, it was based on securing the appearance of the defendants at FF1 million, on securing payment of the damage at FF400,000, and on securing the payment of fines and confiscation of the vessel at FF55,000,000. ${ }^{116}$ The court declared that the release of the vessel would be subject to the payment of the total bond amount of FF56,400,000. ${ }^{117}$

\section{Domestic Courts versus the International Tribunal for the Law of the Sea}

This section illustrates the gap between CLED and RLED in applying confiscation and bond determination rules. ${ }^{118}$ Earlier, the research presented theoretical differences between CLED and RLED in applying their rules. The aim of this comparison, between the International Court (represented by the ITLOS) and national legislation and proceedings, is to prove that there is a wide disparity between the two levels of adjudication (national and international).

\section{A. Confiscation of Vessels}

International application of CLED prohibits the confiscation of vessels, whilst confiscation is permissible in the national application of RLED. ${ }^{119} \mathrm{On}$ an international level, UNCLOS does not clearly prohibit states from confiscating criminal gains. However, the interpretation of Articles 73 and 292 of the UNCLOS implicitly prohibit vessel confiscation. ${ }^{120}$ Articles 73(2) states that '[a]rrested vessels and their crew shall be promptly released upon the posting of reasonable bond or other security. ${ }^{121}$ Article 292 of the UNCLOS states:

Where the authorities of a state party have detained a vessel flying the flag of another State and it is alleged that the detaining State has not complied with the provisions of this Convention for the prompt release of the vessel or its crew upon the posting of a reasonable bond or other financial security, the question of release from detention may be submitted to any court or tribunal agreed upon by the parties or, failing such agreement within 10 days from the time of detention, to a court or tribunal accepted by the detaining State under article 287 or to the International Tribunal for the Law of the Sea, unless the parties otherwise agree...

\footnotetext{
114 Ibid, 37.

115 Ibid, 38.

116 Ibid, 39.

117 Ibid, 39-40.

118 Blakely, L, "The End of the Varsa Saga and the Legality of Australia's Vessel Forfeiture Penalty for Illegal Fishing in its Exclusive Economic Zone" 17(3) Pacific Rim Law and Policy Journal (2008) 678; see also Bing, J "The Notion of Natural Prolongation in the Current Regime of the Continental Shelf: An Afterlife" 12(1) Chinese Journal of International Law (2013) 79.

119 Ibid.

${ }^{120}$ Escher, K-A, "Release of Vessels and Crews before the International Tribunal for the Law of the Sea" 3(3) The Law and Practice of International Courts and Tribunals (2004) 411.

121 UNCLOS, Art. 73(2).
} 
Upon the posting of the bond or other financial security determined by the court or tribunal, the authorities of the detaining State shall comply promptly with the decision of the court or tribunal concerning the release of the vessel or its crew. ${ }^{122}$

ITLOS deals with the consequences of confiscation. ${ }^{123}$ These consequences are the confiscation of the ship by national authorities, confiscation of the catch found on board at the time of seizure, confiscation of any materials or documents used by the crewmembers of the ship. ${ }^{124}$ In that sense, there is a conflict between the national understanding and that of ITLOS in the confiscation of 'criminal' materials. ${ }^{125}$ On the one hand, national courts consider such materials as criminal gain. On the other hand, however, UNCLOS maintains the right of the flag state to demand the prompt release of the ship and the crew. Coastal states have the right to require the posting of a reasonable bond when adjudicating on offense committed on the high seas. ${ }^{126}$ The value of the vessel, which is subject to confiscation in national law, is a contentious issue in the proceedings of ITLOS. ${ }^{127}$ ITLOS compromises the right of the coastal state to monetary damages, which is represented in the price of the vessel as part of the bond paid by the plaintiff. ${ }^{128}$ Hence, there is inconsistency between national and ITLOS in regard to the consequences of the confiscation of crime materials.

In the Grand Prince case (Belize versus France), ITLOS found that the confiscation of the ship was a violation of UNCLOS. ${ }^{129}$ The French authorities failed to comply with Article 73(2) of the Convention; they 'evaded the requirement of prompt release under this article by not allowing the release of the vessel upon the posting of a reasonable, or any kind of guarantee alleging that the vessel is confiscated and that the decision of confiscation has been provisionally executed. ${ }^{130}$ In the Juno Trader case (Saint Vincent and the Grenadines versus Guinea-Bissau), ITLOS found that the objective of Article 292 of the Convention was to 'reconcile the interest of the flag State to have its vessel and its crew released promptly with the interest of the detaining State to secure appearance in its court of the $[\mathrm{m}]$ aster and the payment of penalties. ${ }^{131}$

In the Tomimaru case (Japan versus Russian Federation), ITLOS addressed the question regarding whether the confiscation of a vessel renders an application for its prompt release without object under Article 292 of the Convention. ${ }^{132}$ It recognized the State's right in adopting confiscation measures in domestic legislation. ${ }^{133}$ However, it was

122 UNCLOS, Art. 292(1).

123 Seymour, J, "The International Tribunal for the Law of the Seas; A Great Mistake" 13(1) Indiana Journal of Global Legal Studies (2006) 1, 21.

124 McDorman, T, "An overview of International Fisheries Disputes and the International Tribunal for the Law of the Sea" 40 The Canadian Council of International Law (2002) 119, 131.

125 Ibid, 132.

126 UNCLOS, Art 73(2).

127 Baird, R, "Illegal Unreported and Unregulated Fishing: An Analysis of the Legal, Economic and Historical Factors Relevant to Its Development and Persistence" 5 Melbourne Journal of International Law (2004) 319.

128 International Tribunal for the Law of the Sea, Volga Case (Russian Federation v Australia), Case No. 11, order 2002/1 of Dec. 2, 2002, 53.

129 International Tribunal for the Law of the Sea, The Grand Prince case (Belize v France) [Case no. 8, 2001].

130 Ibid, 8.

131 International Tribunal for the Law of the Sea, The Juno Trader Case, (Saint Vincent and the Grenadines $v$. Guinea-Bissau), [Case no. 13, 2004], 2.

132 International Tribunal for the Law of the Sea, The Tomimaru Case, (Japan v. Russian Federation), [Case no. 15, 2007], 22.

133 Ibid, 70 . 
maintained that these measures should not violate the balance of the interests of the flag state and of the coastal state established in the Convention. ${ }^{134}$ As a result, it concluded:

A decision to confiscate eliminates the provisional character of the detention of the vessel rendering the procedure for its prompt release without object. Such a decision should not be taken in such a way as to prevent the ship owner from having recourse to available domestic judicial remedies, or as to prevent the flag State from resorting to the prompt release procedure set forth in the Convention; nor should it be taken through proceedings inconsistent with international standards of due process of law. In particular, a confiscation decided in unjustified haste would jeopardise the operation of article 292 of the Convention. ${ }^{135}$

At the national level, RLED permits all forms of confiscation, including that of the vessel and criminal gains. In the US, the distinction between civil and criminal forfeiture has changed over time. ${ }^{136}$ The important distinguishing factor between civil and criminal forfeiture in American law is the fact that courts do not consider civil forfeiture a punishment. ${ }^{137}$ Governments resort to civil forfeiture for various other reasons, such as whether it is easier to assert probable cause of the assets, availability of the discovery to all parties in the case and prompt transfer of ownership of the property to the government. ${ }^{138}$ In U.S. v. Ursery, the Supreme Court maintained that in rem civil forfeitures are neither 'punishment' nor criminal for purposes of the Double Jeopardy Clause.' 139 The Double Jeopardy Clause states '[n]or shall any person be subject for the same offense to be twice put in jeopardy of life or limb. ${ }^{140}$ The Court asserts that since the early days of the nation, Congress has authorized the Government to 'seek parallel in rem civil forfeiture actions and criminal prosecutions based on the same underlying events. ${ }^{141}$ Thus, civil forfeiture occurs concurrently with criminal forfeiture. ${ }^{142}$ As for criminal forfeiture, it is in the court's authority to seize the property of the defendant in certain cases. ${ }^{143}$ The Court of Appeal in re Forfeiture Hearing as to Caplin \& Drysdale, Chartered (Petitioner v. United States), asserts the need for criminal forfeiture provisions in common law. ${ }^{144} \mathrm{~A}$ unique feature of forfeiture in the American legal system is that prosecutors do not have to prove that 'a particular asset of the defendant is forfeitable,' they merely have to prove its existence.

In France, confiscation is temporary in nature ${ }^{145}$ and has two aims. The first is to prevent tampering with evidence; authorized bodies take possession of the property under judicial supervision, especially when it is considered part of the evidence.

134 Ibid, 75.

135 Ibid, 76.

136 Steiker, C, "Punishment and Procedure: Punishment Theory and the Criminal - Civil Procedural Divide" 26 Georgetown Law Journal (1997) 782.

137 Pratt, CG and Peterson, W, "Civil Forfeiture in the Second Circuit" 65(3) St. John's Law Review (1991) 653.

138 McCutcheon and Walsh, supra nt 40, 70.

139518 U.S. 267 (1996).

${ }^{140}$ US Constitution, amend. IV, section 1.

141 Ibid.

142 Ibid.

143 Ibid, 73 (1999).

144837 F.2d 637, 649 (1988), Court states that '[c]ongress has already underscored the compelling public interest in stripping criminals such as Reckmeyer of their undeserved economic power, and part of that undeserved power may be the ability to command high-priced legal talent.'

145 Sheehan, VA, Criminal Procedure in Scotland and France: Comparative Study with Particular Emphasis on the Role of the Public Prosecutor (Her Majesty's Stationary Office, 1975), 24. 
Secondly, confiscation acts as a guarantee in case of the defendant's conviction. The judiciary then enforces the confiscation of the seized property. ${ }^{146}$ Likewise, the confiscation is made to ensure that the defendant pays all the fines incurred. ${ }^{147}$

In Germany, the general rule is to forfeit all tools and gains from the crime. German jurists distinguish between two types of forfeiture. The first involves that which affects the defendant directly; forfeiture can be punitive, retributive, compensatory, or preventative. ${ }^{148}$ The second type involves a forfeiture provision that not only affects the defendant's personal capacity, but also targets the defendant's property, gain, or money incurred from the crime. ${ }^{149}$ The German Criminal Code makes a clear distinction between confiscation and forfeiture. ${ }^{150}$ The German court may order forfeiture of any gain acquired from a crime. ${ }^{151}$

Confiscation on the other hand is permissible only if: '1) the perpetrator or inciter or accessory owns, or has a claim to, the objects at the time of the decision; or 2) the objects, due to their nature and the circumstances, endanger the general public, or there exists a danger that they will be used for the commission of unlawful acts. ${ }^{152}$ Some crimes involve mandatory confiscation: treason and endangering external security, ${ }^{153}$ crimes against national defense,${ }^{154}$ counterfeiting of money and stamps, ${ }^{155}$ falsification of documents, ${ }^{156}$ crimes endangering the public ${ }^{157}$ and crimes against the environment. ${ }^{158}$ Similarly, there are some crimes that involve forfeiture only. These include crimes against sexual self-determination, ${ }^{159}$ robbery and extortion, ${ }^{160}$ crimes against competition ${ }^{161}$ and crimes in public office. ${ }^{162}$ Additionally, a third type of crime involves both confiscation and forfeiture. These crimes are falsification of documents ${ }^{163}$ and punishable greed (unauthorized organization of a game of change). ${ }^{164}$

\footnotetext{
${ }^{146}$ Fran. Crim. Pro. C. section 706-30.

${ }^{147}$ Fran. Crim. Pro. C. section 706-36-1.

${ }^{148}$ Benseler, J, "Forfeiture legislation in Germany: Legal Basis and Prosecution Practice" 5(3) European Journal of Crime, Criminal Law and Criminal Justice (1997) 203, 204.

${ }^{149} \mathrm{Ibid}, 204$.

${ }^{150}$ Kilchling, M, "Tracing, Seizing and Confiscating Proceeds from Corruption Within or Outside the Criminal Justice System" 9 European Journal of Crime, Criminal Law and Criminal Justice (2001) 264, 273.

${ }^{151}$ StGB section 73(1).

152 StGB section 74(2).

${ }^{153}$ StGB section 101(a).

154 StGB section $109(\mathrm{k})$.

155 St $G B$ section 150.

156 St $G B$ section 282.

157 StGB section 322.

158 St GB section 330(c).

159 StGB section 181(c).

160 St $G B$ section 256.

161 StGB section 302.

162 St $G B$ section 338.

163 St $G B$ section 282.

164 StGB section 295.
} 


\section{B. Bond Determination}

Bond determination is a challenging question. ${ }^{165}$ In general, a bond is an amount of security with monetary value that the defendant has to pay to the public authority. A bond requirement fulfills several objectives. Firstly, it aims to ensure that the defendant will appear in court. In the event of defendants failing to do so, they forfeit the bond amount in the interest of the public treasury. Secondly, the safety of the victim and the victim's family is considered within the bail amount and the release conditions for the defendant. ${ }^{166}$ Thirdly, the bond is taken to ensure that the defendant pays all his monetary sanctions. If the defendant is convicted, the bond amount is used to pay any fines or compensation incurred. Otherwise, the amount of bond is returned to the defendant. In fishery cases, the international application of CLED requires a reasonable bond to be set, based on exhaustive list of criteria. ${ }^{167}$ The national RLED is, in most cases, left to the discretion of judges and prosecutors. A bond is also a requirement on the international level. On a national level, the competent authorities are not required to issue a bond, or release a defendant on bail. It is left to the discretion of such authorities. ${ }^{168}$ The following paragraph tackles the differences in detail.

On the international level, UNCLOS associates the idea of prompt release with the payment of a 'reasonable bond' ${ }^{169}$ The question of what a reasonable bond amounts to is left unanswered by both national and international courts. ${ }^{170}$ Article 292(1) of UNCLOS States that where

[i]t is alleged that the detaining State has not complied with the provisions of this Convention for the prompt release of the vessel or its crew upon the posting of a reasonable bond or other financial security, the question of release may be submitted to any court or tribunal agreed upon by the parties. ${ }^{171}$

It then requires that the bond shall be reciprocated by the prompt release of the vessel and its crew. Article 292(4) states that 'upon the posting of the bond or other financial security determined by the court or tribunal, the authorities of the detaining state shall comply with the decision of the court or tribunal concerning the release of the vessel or its crew.' As a result, a dispute between national and international courts is raised regarding the level of a reasonable bond.

${ }^{165}$ Corre and Wolchover, supra nt 32, 2: The importance of the bail decision can hardly be exaggerated. It involves balancing the liberty of the individual who (in case of remand before conviction) has been found guilty of no offence against the need to ensure that accused persons are fully brought to trial and the public protected. Quite apart from depriving him of his liberty, a remand in custody may often have other harmful effects... on the other hand, it is rightly a matter of serious concern if a person granted bail absconds or commits offences while on bail.

${ }^{166}$ California Constitution, 28 section 8, para 3.

${ }^{167}$ Franck, E, "Reasonable Bond in the Practice of the International Tribunal for the Law of the Seas" 32(2) California Western International Law Journal (2001-2002) 303, 331.

${ }^{168}$ Damner, HR and Albanese, JS, Comparative Criminal Justice System, (5th ed, Wadsworth Cengage Learning, 2013), 136.

169 Devine, DJ, "Relevant Factors in establishing a reasonable bond for prompt release of vessel under article 292(1) of the United Nations Convention on the Law of the Sea 1982" 27 South African Yearbook of International Law (2002) 140; see, Larkin, J, "UNCLOS and the balance of Environmental and Economic Resources in the Arctic" 22 Georgetown Environmental Law Review (2009) 307.

${ }^{170}$ Devine, Ibid, 142.

${ }^{171}$ Song, HY, "Prompt Release of Fishing Vessels: The Hoshinmaru and Tomimaru Cases (Japan v. Russian Federation) and the Implications for Taiwan" 25 Chinese (Taiwan) Yearbook of International Law (2007) 21 
The question of bond determination is a common issue in ITLOS proceedings. In the Volga case, ITLOS found that the bond sought by the Australian authorities was 'not reasonable within the meaning of article 292 [of UNCLOS]. ${ }^{172}$ ITLOS determined the reasonable amount of the bond to be AU\$1,920,000. ${ }^{173}$ Based on Australian jurisprudence, this amount was deemed reasonable. ${ }^{174}$ However, ITLOS found that setting a bond in respect of three crew members did not serve any practical purpose. ${ }^{175}$ In the Hoshinmaru case, ITLOS considered the reasonableness of the bond (set by the Russian Federation with respect to the Japanese vessel) on the basis of two points. ${ }^{176}$ Firstly, ITLOS found that the Japanese vessel did hold a valid fishing license. ${ }^{177}$ Secondly, there is strong bilateral cooperation between Russia and Japan in the field of conservation and reproduction of salmon and trout. ITLOS stated 'a number of factors are relevant in an assessment of the reasonableness of bonds or other financial security. They include the gravity of the alleged offenses, the penalties imposed or imposable under the laws of the detaining State, the value of the detained vessel and of the cargo seized. ${ }^{178}$ As a result, ITLOS lowered the bond from 22 to 10 million rubles. ${ }^{179}$

In the $M / V S A I G A$ case, ITLOS stated 'the criterion of reasonableness encompasses the amount, the nature and the form of the bond or financial security. The overall balance of the amount, form and nature of the bond or financial security must be reasonable. ${ }^{180}$ ITLOS lists the factors that must be considered as a basis for setting the bond; ${ }^{181}$ it states that these factors include 'the gravity of the alleged offenses, the penalties imposed or imposable under the laws of the detaining State, the value of the detained vessel and of the cargo seized, the amount of the bond imposed by the detaining State and its form. ${ }^{182}$ It takes both the gravity of the alleged offenses and the penalties imposed by the coastal authority into consideration. ${ }^{183}$ ITLOS found the amount set for the detained vessel not reasonable and took the appropriate measures to release the master of the vessel. ${ }^{184}$

${ }^{172}$ Volga case (2002) 88.

173 Ibid, 90.

${ }^{174}$ Ibid, 73

175 Ibid, 64.

${ }^{176}$ International Tribunal for the Law of the Sea, Hoshinmaru case (Japan v Russian Federation) (Case no. 14 2007), 59.

${ }^{177} \mathrm{Ibid}, 50$.

178 Ibid, 65.

179 Ibid, 100.

${ }^{180}$ International tribunal for the Law of the Sea, M/V Saiga Case no. No. 2 (St. Vincent v. Guinea), (Order of Jan. 20, 1998, Rep. 30), 2.

181 Assonitis, G, M/V SAIGA Case, 50 RHDI (1997) 590; see Kwiatkowska, B, "Inauguration of the ITLOS Jurisprudence: The Saint Vincent and the Grenadines v. Guinea M/V Saiga Cases" 30 Ocean Development and International Law (1999) 44; see also, Bantz, CB, International Tribunal for the Law of the Sea, "M/V Virginia G Case (Panama. Guinea- Bissau)" 53 International Legal Materials (2014) 1163; White, M, "ITLOS and the Volga Case: The Russian Federation v. Australia" 17 Australia and New Zealand Maritime Law Journal (2003) 41.

182 Lowe, V, "Advocating Judicial Activism: The ITLOS opinions of Judge Ivan Shearer" 24 Australian Yearbook of International Law (2005) 145. See also, McDorman, T, "Overview of International Fisheries Disputes and the International Tribunal of the Law of the Sea" 40 Chinese Yearbook of International Law (2002) 135.

${ }^{183} M / V S A I G A, 68$.

${ }^{184}$ Ibid, 72. 
In the Monte Confurco case, ${ }^{185}$ ITLOS considered the conflict between the flag and the coastal States in relation to Articles 73 and 292 of UNCLOS. ${ }^{186}$ The interest of the coastal State was to protect its waters from damage, ${ }^{187}$ while that of the flag State was to promptly release the vessels (Article 73). ${ }^{188}$ These compromises gave ITLOS the ability to set a reasonable amount of bond. ${ }^{189}$ Among the factors determining the amount of the bond, ITLOS placed special emphasis on the gravity of the offenses, as well as the value of the fish and the fishing gear seized. ITLOS asserted that the gravity of the offenses has always been taken into consideration. ${ }^{190}$

In the Camouco case, the ITLOS once again identified the factors relevant in an assessment of the reasonableness of bonds. It referred to legal precedents; ${ }^{191}$ offenses committed by the master of the vessel were considered grave under French law. ${ }^{192}$ It stated that the value of the fish found on board the vessel was taken into consideration when determining the reasonableness of the bond. ${ }^{193}$ As for the detention of the crew members, ITLOS found that it was appropriate to release them based on the circumstances of the case once the master of the vessel had paid the new bond. ${ }^{194}$

On a national level, in most developed countries, bond determination is left to the discretion of the investigating authority. The 'Excessive Bail Clause' of the US Constitution maintains '[e]xcessive bail shall not be required, nor excessive fines imposed, nor cruel and unusual punishments inflicted. ${ }^{195}$ The Eighth Amendment does not define 'excessive bail'. ${ }^{196}$ The US Supreme Court maintains that 'individualized findings, procedural protections, and the discretionary nature of the denial of bail are important factors in upholding detention without bail. ${ }^{197}$ In Carlson v. London, the US Supreme Court held that the Eighth Amendment does not grant the right to bail in all cases; it only maintains that the bail shall not be excessive. ${ }^{198}$ The California Constitution entitles every defendant to be released on bail, ${ }^{199}$ unless the crime is punishable by death. ${ }^{200}$ Even though the judge has the right to set a bond, it is rarely used to detain the defendant. ${ }^{201}$

In France, the system is based on the 'speedy trial' principle. A defendant cannot be detained for more than 48 hours and does not have a right to be released on bail. There is nothing in the French Criminal Procedure Code that refers to the bailing of a

185 International Tribunal for the Law of the Sea, Monte Confurco, (No. 6) (Seychelles v. France), (Case No. 6 , Order 2000/2 of November 27 2000), 27; the shipping vessel carried the Seychelles flag.

186 UNCLOS, Art. 72 and 292.

187 Ibid, Art. 292.

188 Mensah, T, "The Tribunal and the Prompt Release of Vessels" 22 International Journal of Marine and Coastal Law (2007) 430.

189 Chandrasekhar Rao, P, "ITLOS: The First Six Years" 6 Max Plank Institute (2002) 233; See also, Franck, E, "Reasonable Bon in the Practice of the International Tribunal for the Law of the Sea" 32 California Western International Law Journal (2001) 308.

190 International Tribunal for the Law of the Sea Camouco (No. 5) (Panama v. France), (Case No. 5, Order 2000/1 of January 17, 2000), 73.

191 Ibid, 76.

192 Ibid, 79.

193 Ibid, 86.

194 Ibid, 90.

195 US Constitution. Amend XIV section 2.

196 Gassman, K, "Unjustified Detention: The Excessive Bail Clause in Removal Proceedings" 1 American University Criminal Law Brief (2009) 39.

197 Gassman, K, "The Excessive Bail Clause in Removal Proceedings" 4 Criminal Law Brief(2009) 35.

198 Section 342 US 524, 537 (1952).

199 California Constitution, 28 section 8, para 3.

${ }^{200}$ Gustafson, R, "Bail in California" 44 California Law Review (1956) 816.

201 Cal. Pen. Cod section 1271. 
defendant as an option for release. The Judge of Liberties and Detention rarely grants it. Nonetheless, certain defendants falling under certain categories specified in the Criminal Procedure Code will be detained until trial. Pre-trial detention in France occurs in only two cases: (1) when the person under judicial examination risks incurring a sentence for a felony; ${ }^{202}$ and (2) when the person under judicial examination risks incurring a sentence for a misdemeanor of at least three years imprisonment. ${ }^{203}$ The purposes of pre-trial detention are: (1) to preserve material evidence or clues or to prevent either witnesses or victims or their families being pressurized or fraudulent conspiracy between persons under judicial examination and their accomplices; (2) to protect the person under judicial examination, to guarantee that he remains at the disposal of the law, to put an end to the offense or to prevent its renewal; (3) to put an end to an exceptional and persistent disruption of public order caused by the seriousness of the offense, the circumstances in which it was committed or the gravity of the harm that it has caused. ${ }^{204}$

In Germany, the legislation delegates the power of determining the bond and addressing the issue of excessive bond to the judge. The general rule in the German criminal system is that the defendant is not necessarily detained before trial. Even though the judge has the right to set a bond, this right is rarely exercised.$^{205}$ One study found that only $12 \%$ of defendants were released on bail. ${ }^{206}$ The general rule is that the prosecutor processes the case without arresting the defendant, unless there is major 'concern that the defendant would foil the process by absconding. ${ }^{207}$

\section{Conclusion and Recommendations}

Accurate predictions may save lawyers from lengthy and costly litigation processes. Countries, lawyers and law enforcement officers have the right to predict judgments. This right reduces the cost of resorting to national and international adjudication. ${ }^{208}$ If lawyers and law enforcement officers were aware of the ITLOS precedents, they would likely adhere to it. The existence of two different sets of systems, CLED and RLED that govern the same behavior violates litigation rights in legal prediction. This article aims to provide guidance to countries and lawyers on the judicial behavior and approach of ITLOS. While some countries adopt RLED, ITLOS changes RLED to CLED.

Even though this study focuses on fishery cases, it urges countries to abolish their RLED and to reform their domestic environmental laws in order to abolish the uncertainty in fishery cases. ${ }^{209}$ It calls for them to comply with the international adjudication that differs from their understanding and practice. ${ }^{210}$ It helps avoid any discrepancies that may arise between national and international courts. Parties have the right to predict ITLOS proceedings. The change in nature of the dispute from RLED to

\footnotetext{
${ }^{202}$ French CCP, Art. 143.

203 French CCP, Art. 143.

204 French CCP, Art. 144.

205 St OP, Section 116.

${ }^{206}$ Frase, SR and Weigend, T, "German Criminal Justice as a Guide to American Law Reform: Similar Problems, better Solutions?” 18 Boston College of International and Comparative Law Review (1995) 329.

207 Ibid, 327.

208 Charnovitz, S, "A World Environment Organization" 27 Columbia Journal of Environmental Law (2002) 323.

209 Guttel, E and Harel, A, "Uncertainty Revisited: Legal Prediction and Legal Post diction" 107 Michigan Law Review (2008-2009) 468

210 Ibid, 468.
} 
CLED prejudices the right of parties to predict ITLOS proceedings. ${ }^{211}$ ITLOS adopts the CLED approach in settling disputes, while national courts adopt the RLED approach. ${ }^{212}$

In its jurisdiction, ITLOS often considerably changes the nature of the original dispute from RLED to CLED. ITLOS is not likely to change its understanding of the nature of the dispute, as illustrated in the cases presented earlier. It is now the role of national legislatures to adopt this understanding of CLED, especially in fishery cases. This change will not only help countries in the event that plaintiffs resort to ITLOS, but will also ensure the equality principle between those who can resort to the tribunal and those who cannot. ${ }^{213}$ It is seemingly evident that should a case involve RLED, this likely involves a waste of resources or instances of injustice to parties concerned.

Once ITLOS exercises its jurisdiction, the nature of the conflict changes from a criminal to a civil one. It has the legal tools and the desire of the disputing parties to change its role. It makes a considerable change to the nature of the dispute. As mentioned above, this change helps the court balance the interests of the coastal State and those of the flag State. Whenever a case involves criminal liability, the coastal State has to be aware that such liability, as well as its gain from such liability, is subject to reexamination by ITLOS.

www.grojil.org

${ }^{211}$ Manning, P, "Reflections on Risk Analysis, Screening and Contested Rationalities" 48 Canadian Journal of Criminology and Criminal Justice (2006) 460.

212 Escher K-A, "Release of vessels and Crew Before the International Tribunal for the Law of the Seas" 3 Law and Practice of International Courts and Tribunals (2004) 205 and Ratiliff, D, "Dispute Resolution and Environmental Security" 20 Hague Yearbook of International Law (2007) 65.

${ }^{213}$ Seymour, J, "International Tribunal for the Law of the Sea: A Great Mistake?" 13 Indiana Journal of Global Legal Studies (2006) 1. 